\title{
The Rules of Red River: The Council of Assiniboia and its Impact on the Colony, 1820-1869
}

Nelly Laudicina, University of Ottawa and Université de Paris IV, la Sorbonne.

\begin{abstract}
The Council of Assiniboia, whose members were appointed by the Hudson's Bay Company (HBC), held administrative, judicial and legislative powers over the Red River colony. The Council's main challenge was to remain relevant to the Red River settlers while simultaneously adhering to the priorities of the HBC. Through numerous petitions and occasional riots the population of Red River acquired both representation and power in the Council. The aim of this paper is to discuss the relations of power underlying the transformation of not only the Council, but of the colony as a whole.
\end{abstract}

\section{Introduction}

My essay follows the shifting power relations within the state of Assiniboia. ${ }^{1}$ The lack of literature concerning Red River's first state doesn't give justice to the role it played in the life of the colonists. Indeed, the council of Assiniboia had a tremendous impact on the way the colony developed, mostly through the people's actions. Over a

${ }^{1}$ Also known as the Red River Colony 
relatively short period of time, the young colony's state went through three different phases which were drawn out by the constant tug between the people and the state. The Council of Assiniboia was at first a smoothing system struggling to establish its authority against the Hudson's Bay Company. In 1835, the council's second phase began when it was taken over by the HBC. The Company worked at turning the state of Assiniboia into a stronger, more threatening apparatus, often protecting the HBC's interests over those of the inhabitants. The third phase came about as the population's aggravation peaked during the landmark Sayer Trial of 1849. Following that event, the council was turned into a strongly democratized state by the Assiniboia inhabitants. The aim of this article is to provide an analysis of the impact the state of Assiniboia had on the settlement and its inhabitants.

\section{Early accounts of the Council of Assiniboia}

Historians of the Métis have generally overlooked the colony of Assiniboia's first state. General historical accounts of Red River such as Marcel Giraud's seminal Le Métis Canadien, George F. G. Stanley's Birth of the Canadian West or Arthur S. Morton's A History of the Canadian West only mention the Council in passing, generally deeming it to have been weak, and dismiss it as an apparatus that had no particular impact on the settlement or its inhabitants. ${ }^{2}$

2 Giraud, Marcel. Le Métis Canadien : Son rôle dans l'histoire des provinces de l'Ouest (en deux tomes). Paris: Institut d'éthnologie, Musée de l'homme, Paris, 1945, Stanley, George F.G. - The Birth of Western Canada : A History of the Riel 
Later scholarly contributions such as Frits Pannekoek's $A$ Snug Little Flock: the Social Origins of the Riel Resistance of 1869-70, laid stress on judicial cases, whereas Kathryn Bindon and Robert Baker discussed the impact that Adam Thom, the infamous recorder of Rupert's Land, had on Red River. ${ }^{3}$ The common strain in the scholarly literature on the state in Assiniboia is the attempt to assess the Council in terms of what it did, rather than through what the people did with it. Ultimately, Riel's provisional government and the Métis resistance of 1869 completely overshadowed the importance of the first state of the Canadian Western Interior. The Council of Assiniboia was indeed a somewhat rudimentary state but it played a compelling role in shaping the colony, in great part through the actions of the settlers.

In the early 1800s, Thomas Douglas, $5^{\text {th }}$ Earl of Selkirk began searching for a large land grant to conduct a colonizing scheme designed to relocate the dispossessed Highlanders of Scotland. In 1811, Selkirk acquired a land grant of 116,000 square miles in British North America within the Hudson's Bay Company territories of Rupert's Land. The colony of Assiniboia was to be founded at the forks of the Assiniboine and Red Rivers, in the heart of a

Rebellions. Toronto: University of Toronto Press, 1960, Morton,Arthur S.. A History of the Canadian West to 1870-71 (Toronto: University of Toronto Press, 1939).

${ }^{3}$ Frits Pannekoek, A Snug Little Flock: The Social Origins of the Riel Resistance, 1869-70. Winnipeg: Watson \& Dwyer Publishing, 1991, Bindon, Kathryn. "Hudson's Bay Company Law: Adam Thom and the Institution of Order in Rupert's Land 1839-54," in Essays in the History of Canadian Law, ed. David Flaherty (Toronto: The Osgoode Society, 1981), 1:57, Baker, Robert H, "Creating Order in the Wilderness: Transplanting the English Law to Rupert's Land, 183551" Law and History Review, Vol. 17, No. 2 (Summer, 1999): 209-246 
region torn by conflict between the two great fur trade companies: the Hudson's Bay Company and the North West Company.

From the 1820s to the 1860s, the Red River Colony formed a distinct community based on its ethnically and socially contrasted population, its geographical situation and its economic endeavors. The creation of a Council to rule the colony of Assiniboia was not a concerted decision on the part of the inhabitants; but came from Lord Selkirk himself. As early as 1813, Selkirk was concerned about the safety of "his" incoming settlers. While he and Miles MacDonell (the first Governor of the colony) stressed "the necessity of an efficient judicature for the colony," ${ }^{4}$ they were undecided about what type of judicial structure to apply since the territory was located in Rupert's Land, therefore implicitly placing it under the Royal Charter of 1670. In their correspondence, Selkirk and MacDonell consistently discussed the benefits of creating a Council authorized to "punish offenses according to the law of England." 5 Selkirk was conscious of the threat that the North West Company represented. The project of the Council was partly meant to protect the settlement from that company, which had been unable to impede Lord Selkirk's projects prior to their implementation and was now less than thrilled to see settlers coming into its hunting grounds.

\footnotetext{
${ }^{4}$ Letter from Selkirk to Miles Macdonell, June 13, 1813. Selkirk Papers Vol.II in E.H Oliver, The Canadian North-West: Its Early Development and Legislative Records, Vol. I. (Ottawa: Government Printing Bureau, 1914), 178.

5 Ibid., 178-179. 
In 1816, a group of incoming settlers on their way to Red River were met by a party of Nor'Westers, led by Cuthbert Grant, a well-respected Métis ${ }^{6}$ leader. During infamous "Battle of Seven Oaks," the settlers suffered 22 casualties and were forced to turn back. ${ }^{7}$ As a result of the fear of another attack by the Nor'Westers, Selkirk proceeded to provide the colony with a government in the form of a Council. The Council was created to keep order on the "lawless" Nor'Westers, natives and other Métis deemed threatening by the Governor of Assiniboia, Robert Semple, who made several accusations against the Nor'Wester Duncan Cameron of:

Collecting, harbouring and encouraging Halfbreeds and vagabonds with the avowed purpose of destroying an infant British Colony. Through the means of these men headed by yr. clerks or the clerks of the N.W.Co., such as Cuthbert Grant, Charles Hesse, Bostonais Pangman, William Shaw and others of burning a fort, a mill, sundry house, carts, ploughs and instruments. Of encouraging Indian tribes to make war upon British subjects attempting to colonize, representing to them according to their ideas that cattlemen would spoil their lands and make them miserable ${ }^{8}$

6 I use the term "Métis" in reference to all mixed-blood individuals partaking in the fur trade economy.

${ }^{7}$ L. Dick, "The Seven Oaks Incident and the Construction of a Historical tradition, 1816 to 1970," Journal of the Canadian Historical Association, 2, 1991 91-113.

${ }^{8}$ Letter from Robert Semple to Duncan Cameron, March 31, 1816, in E. H.

Oliver, TheCanadian North West, 203-4. 
Following the merger of the Hudson's Bay Company and the North West Company in 1821, Red River became a "retirement centre" for many employees of both the HBC and NWC, who settled in Assiniboia with their native wives and Métis children. The majority of European settlers left the settlement for the United States and as a result of this emigration as well as the fusion of the companies, the colony's demographics proved quite different from those Selkirk had had in mind. The Council thus lost part of its original raison d'être. From 1821 to 1869 the main challenge of the Council would consist in remaining relevant to the settlers while simultaneously supporting the higher power to which it was beholden: the Hudson's Bay Company.

\section{Starting from scratch: The arduous shaping of authority, 1820-1840}

In the 1820s, following the merger of the North West Company and the Hudson's Bay Company, the Council of Assiniboia consisted of essentially three steady members. These were Governor Andrew Bulger, Thomas Thomas and John Pritchard, who were joined by a number of members whose attendance was irregular. ${ }^{9}$ Bulger was unhappy with the position he occupied because he did not receive any specific details about his actual role in the colony. He hadn't been warned for instance, that he would be granted judicial tasks, only to be irritated when he learnt

9. James White, et al in E. H. Oliver, The Canadian North West, 33-34. 
that his title meant little to the HBC officers, who openly sapped his authority.

I did not expect when I left England to be called upon at any time to perform any judicial functions for which I am not competent in point of ability, nor qualified by law. The management of the settlement for one year was all that I had agreed to undertake; and it was, as I understood, to give me authority in the eyes of the settlers that I could possibly have, if merely the agents of the executors, that a commission as governor of Assiniboia was granted to me. No provision appears to have been made to secure to me the respect and obedience of the company's officers and servants in this district. They treated me as if I had no authority at all...Before the resolution of 29th May arrived the mischief was done; even my title had by that time been changed to «Monsieur le Capitaine» while that of «Monsieur le Gouverneur» had been transferred to Mr Clarke. ${ }^{10}$

Mr. Clarke was a Hudson's Bay Company chief factor who had fancied (and was denied) Bulger's position following a feud with Governor Simpson. ${ }^{11}$ Bulger continually butted heads with Clarke, mainly because he

\footnotetext{
10 Letter from Andrew Bulger to Andrew Colvile, December 7, 1822. Bulger Correspondence M152 E. H. Oliver, The Canadian North West, 43-44.

11 Giraud, 737.
} 
and his officers kept abusing their powers. In a notable incident, one of Clarke's employees (a clerk) injured a servant (Risk Kipling), who then came to Bulger to demand justice. When Bulger reported the incident to George Simpson, the Governor General, Bulger was told that he was "not authorized to interfere in the internal affairs of the Honorable H.B.C., whether in civil or criminal matters without the presence and assistance of the company's representative in the said district of Ossiniboia."12

Bulger's position was awkward because while he was the authority settlers would turn to when in difficulty, ${ }^{13}$ the larger context of Rupert's Land, dominated by the HBC and the fur trade, severely limited any powers granted to him by Lord Selkirk. The dynamics of law and order were still those of the fur trade of the Western Interior, and as far as the actors of that trade were concerned, the colony did not and should not alter the manner in which they conducted their business. Consequently, Governor Bulger was insignificant and powerless in the eyes of high-ranking HBC officers, the only offenders of the few reported crimes in Red River. ${ }^{14}$ Lord Selkirk, Miles MacDonell and Andrew Bulger all agreed on the fact that a military force was essential, as Bulger put it, to "prevent the country from becoming very soon a den of

12 Minutes of the Council of Assiniboia, May 3, 1823. Letter read during the meeting of the Council, in E. H. Oliver, The Canadian North West, 235-238. 13 E. H. Oliver, The Canadian North West, 44.

14 Minutes of the Council of Assiniboia, May 3, 1823. Letter read during the meeting of the Council, in E. H. Oliver, The Canadian North West, 235-239. 
thieves, for no honest man will remain in it."15 Bulger felt that several things, such as a jail, magistrates and power to restrain the evil propensities of the population, were essential to maintaining the peace in the colony. ${ }^{16}$ The latter ironically came into existence when the $\mathrm{HBC}$ reacquired the territory and took over the Council.

\section{The Hudson's Bay Company Take-Over: Restructuring and expanding the Council}

By 1835, the population of Assiniboia had increased substantially to approximately 3,679 people. ${ }^{17}$ The Council, headed by Governor George Simpson, underwent restructuring in 1835. It was now granted executive, legislative and judiciary powers. In its new form, the Council was to be supported by a courthouse and a jail, and was in all likelihood devised to promote law and order according to European principles. To justify the newly imposed government, in spite of the peaceful state of the colony, Governor Simpson introduced the new laws of Assiniboia with the following statement:

The personal influence of the governor and Council, and the little more than nominal support

${ }^{15}$ Letter from Andrew Bulger to Andrew Colvile, 1822(?) Dominion Archives, Bulger Correspondence II M.150p.167 in E. H. Oliver, The Canadian North West, 224.

16 Letter from Andrew Bulger to Andrew Colvile (?), Sept. 8, 1822. E. H. Oliver, The Canadian North West, 225.

17 The figure of 5000 given by the Minutes of Council of February 12, 1835

seems to be an exaggeration, my figure is the one given by the census of 1835 .

Oliver, North-West 267. 
afforded by the police, which together with the good feeling of the public, have heretofore been its principal safeguard, are no longer sufficient to maintain the tranquility and good government of the settlement, so that although rights of property have of late been frequently invaded and other serious offences been committed. ${ }^{18}$

Safety was the leading argument in HBC officials' reports and letters when arguing for the necessity of taking over and restructuring of the Council of Assiniboia. ${ }^{19}$ However, as noted above, the majority of crimes reported during the Bulger administration were carried out by highranking HBC officers. Set against a background of fairly typical fur trade society violence, far from the eyes of English law, which was supposed to be represented partly and in spirit by the Council, the HBC kept the Council it had copiously mocked and baffled. ${ }^{20}$ The company's record makes it hard to believe that a stronger, more powerful Council was designed to protect the colony; but rather suggests that it was aimed at securing the company's hold on Red River.

The first resolution taken by the new Council was to levy a tax of $7.5 \%$ on imported goods The Council's argument was that it needed to defray expenses incurred

18 Minutes of Council. E. H. Oliver, The Canadian North West, 267.

19 E. H. Oliver, The Canadian North West, 248, 258-260.

20 A letter by George Simpson is particularly defamatory, see extract of letter from George Simpson to A. Colvile, May 31, 1824. Selkirk Papers XXVI-XXVII, 8221. Oliver, North-West, 258. 
towards the maintenance of tranquility in the colony. ${ }^{21}$ The Council followed this resolution with others aimed at building a courthouse and jail, the formation of a committee for the management of public works, and the creation of a volunteer corps of 60 officers and privates. Maintaining this force cost $€ 400$ per annum and was financed by the new taxes. It was decided to divide the settlement into four districts (which would soon become three), and to have magistrates operate in each district in order to deal with petty offenses and debts. The governor was to hold a general court at his residence "on the last Thursday of every quarter." 22

The minutes of the new Council contain a noticeably lengthy passage on the volunteer corps, concluding that it should be in "unison with and conformable to the practice and usages connected with such service in the British Army." 23 The government now in effect was hardly representative since it was composed of Anglo-Saxon males who were not elected, but appointed by the HBC. As a result of this small volunteer "army," charged with keeping the settlement safe at the people's expense, as well as the promise of a court and jail, this newly reconstituted Council posed a more definite threat to the colonists than it had previously done. Soon, because the Hudson's Bay Company realized that neglecting the representation of Red River's francophone majority would create tension, the Council nominated its first francophone Councilors: Mgr.

\footnotetext{
21 Minutes of Council. February 12, 1835. Oliver, North-West, 267.

22 Ibid., 270.

23 Ibid., 272.
} 
Provencher, the French-Canadian bishop of the colony, as well as the Métis leader Cuthbert Grant. ${ }^{24}$

From 1835 to 1839, the Council kept making adjustments in the organization of the administration of justice. A major change was in 1822-23, when two separate Councils emerged. These were the Council of Rupert's land, made up of twenty employees of the HBC and headed by George Simpson. Simpson also held authority over all of the company's territories for judicial and other purposes. The other council was the Council of Assiniboia, which was made up of the "leading" members of the Red River community. This Council was presided over by the Governor of Assiniboia. ${ }^{25}$ This structure placed a civil Council under the jurisdiction of a commercial one, a situation which would soon appear aberrant for a great part of the population.

However, as a result of this further division of powers, the Council of Assiniboia was now able to focus on local issues. In 1839, the Council introduced a resolution according to which sheriffs were to be appointed for each district, and under which every landowner would be held qualified and liable to act as a juror. In order to choose the jurors, the Sheriffs were each required to compose a list of twelve names, making a total of 36 , from which nine would be chosen at random. Up until 1839, the Council's resolutions dealt mostly with problems involving damage done to property in the colony (e.g. pigs roaming at large,

24Ibid., 282.

25 Ibid., 285

Past Imperfect 
stallions ranging, cattle destroying properties). ${ }^{26}$ This justified the nomination of landholders to juries, as they had to deal with such problems more frequently than hunters and traders who regularly took leave of the settlement to make their living. Nevertheless, this practice did constitute an initial step towards the exclusion of a section of the population from the colony's affairs. ${ }^{27}$

During the period the Council frequently discussed and passed numerous resolutions concerning the sale of alcohol to the Natives, which coincided with authorizations to erect distilleries. ${ }^{28}$ It is interesting to note that the HBC both made and controlled the sale of liquor, which, according to the minutes of Council and the court records, provided one of the most recurring source of tension in Red River.

Of abuse and consequences: The critical years, 18391849

In 1839, the appointment of Adam Thom as recorder of Rupert's Land and Councilor of Assiniboia marked a turning point for the colony's legislative system. Thom was the only person who was a member of both Councils.

${ }^{26}$ Minutes of Council, May 4, 1832. E. H. Oliver, The Canadian North West, 263265.

${ }^{27}$ Questions remain though as to who was excluded and on which grounds. The Métis who were occupying loghouses in between hunting trips were most likely part of the excluded population, but this would require further examination of the jurors' names in the court records of Assiniboia. (Ross, Alexander. The Red River Settlement: Its Rise, Progress and Present State, London, 1856. p94-96).

28.Minutes of Council, June 16, 1837. E. H. Oliver, The Canadian North West, 279281. 
George Simpson, despite warnings of Thom's francophobia, 29 appointed him to restructure the settlement's legal system. He was a Scottish born-andraised journalist and lawyer who had among other things participated in the writing of the Durham Report in Lower Canada. The infamous main thesis of the report was that the francophone was a backward people and needed to be assimilated by the English. His appointment was a provocative move in the predominantly French speaking Red River community. Moreover, Thom rewrote the rules and regulations both for Rupert's Land and Assiniboia with a rigidity and formality that contrasted with the still very rural and rudimentary state of the colony.

In 1841, the Laws of Assiniboia were not a simple list of resolutions, but a thematically organized book of laws, including those few enumerated above, although in a far more augmented version. The following subjects were now rigidly regulated: "Fires, Pigs, Fences, Hay, Stallions, Horse-taking, Maintenance of prisoners, Intoxicating Indians, Distillation, Roads and Bridges, Custom Duty, Police, and Courts." Also, for the first time these laws were to be posted in the settlement and distributed by the inhabitants who were willing to do so. The clergy had previously done this on a voluntary basis. ${ }^{30}$ The laws were penned in an irksome and somewhat ridiculous style that

29. He had participated in the Durham report and as a journalist had written numerous articles against French Canadians in the Settler of which he was the editor, and in the Herald (under various pseudonyms). Dictionary of Canadian Bibliography online,

http://www.biographi.ca/EN/ShowBio.asp?BioId=39990\&query= 30 Minutes of Council, June 25, 1841, in E. H. Oliver, The Canadian North-West, 295-306. 
betrayed how little Adam Thom seemed to realize the awkwardness and inadequacy of the laws' content and form. Using flowery language in written rules and regulations for a population of which the majority was illiterate and francophone was at best an exercise in futility, at worst an insult to the greatest part of the settlement who could not understand the laws governing them.

Between 1845 and 1847, revisions to the laws were made in order to bring them in line with some of the settlement's realities. Alcohol was a central element of this reform, substantial additions being made in the "Intoxicating of Indians" and the "distillation" sections, as well as in the regulations concerning soldiers and the illegal sale of alcohol to them. The subject of alcohol was discussed in practically every Council meetings and the court records of the period (1845-47) show that out of the 41 cases brought to trial, 17 were liquor-related. ${ }^{31}$ The essence of the adjustments made by the Council was that the HBC wished no one to make a profit or exercise power from the selling of spirits (except the company itself), judging that it was best able to control the population's consumption. The Council's paradoxical position defending the economic advantages of the HBC while trying to keep the settlement peaceful - clearly demonstrates its limited ability to pursue the ongoing struggle over alcohol.

In the mid 1840s, the Minutes of Council demonstrate a timid attempt to encourage the development of the colony, mainly through the committee of economy,

31 Provincial Archives of Manitoba. District of Assiniboia, Courts Records. 
which gave grants to buy books from England and aimed to help the population by having a carding machine and a model of a fulling mill brought to Red River. The Council also organized various contests rewarding, for instance, the best specimen of fabric, or the best cheese. This was obviously aimed at encouraging and promoting the efforts of the settlers, although only a certain type of settler, because not everyone was an agriculturalist. A part of the population - namely the hunters and traders who did not live in the colony year-round - was excluded from such community life, because they did not participate in the same economy. 32

\section{Departure of the Troops: The Council in Dire Straits}

The Minutes of Council finally mention the absentees in November 1847. In a letter to "the Honourable, the Governor, Depy. Gov. And Committee of the Hudson's Bay Company"33, the Council of Assiniboia begs the governor and committee not to withdraw the troops who acted as police. This letter is compelling because it gives a description of the dynamics of the colony that includes people whose presence and lifestyle the Minutes of Council never otherwise acknowledge in. In explaining the reasons why the troops are needed, the letter states that the colony is very vulnerable to "savages" in the Summer, as the "hardier half" of the male population

32 Minutes of Council, June 28, 1847," in E. H. Oliver, The Canadian North-West., 334-338.

33 Ibid., 340. 
is away hunting. The other argument put forth is that "many" settlers "feel little of that dependence of man on man which forms the true cement of society," putting at risk the "more substantial classes of the community" as well as the "progress of civilization." 34

This letter is contradictory because it states that half of the male population is away in the summer, asserting that these people (the Métis or Halfbreed ${ }^{35}$ hunter-traders) constitute a form of protection against the natives, but it goes on to state in a vague phrase that "many people" are unaccustomed to the "restraints of social life," thereby justifying the presence of an armed force. The final part of the letter is also instructive in that it demonstrates that even prior to the troops' presence, nothing noteworthy happened. Council minutes cited above make this point explicit by noting that "though none of these evils was fully realized previously to the establishment of our garrison, yet that comparatively happy result was more or less owing to the dread, that sooner or later a garrison might bring a day of retribution in its train." 36

The letter does not state, however, that the Métis had become bothersome to the Hudson's Bay Company as a result of the independent trade that they conducted - trade that led the HBC to use intimidation in an attempt to suppress it. ${ }^{37}$ Thus, the soldiers were stationed in the

34 Ibid., 340-341.

35 Both terms (Métis and Halfbreeds) are used interchangeably to speak of the biracial population participating in the fur trade. 36 Ibid., 340.

${ }^{37}$ Giraud, Marcel. Le Métis Canadien : Son rôle dans l'histoire des provinces de l'Ouest.Tome 2. Paris: Institut d'éthnologie, Musée de l'homme, Paris, 1945. 899, 907. 
colony to protect the HBC's monopoly in the face of the serious challenge posed by the Métis, that portion of the population that, because it did not farm, failed to encourage the "progress of civilization" in the settlement. George Simpson made this clear in a letter to the Governor of Red River, Sir John Henry Pelly:

The presence of military establishments in the Interior can be productive of little benefit to us at any other point than Red River Settlement, \& there one is absolutely necessary to the existence of the Fur trade, not in reference to any difficulties with the United States only, but as a means of protection against the inhabitants of the Settlement, as with the feeling at present existing on the minds of the half-breeds, it will be quite impossible to protect the trade or enforce our laws without the presence of military at that point... ${ }^{38}$

The letter written by the Councilors of Assiniboia discussed previously on page 11 suggests that the greater part of the settlement and by deduction the mixed-blood population since it formed the colony's overwhelming majority, was not "accustomed to the restraints of social life" and incapable of living in peace and order without a

38 Morton, Arthur S. A History of the Canadian West to 1870-71. Being a history of Rupert's Land (The Hudson's Bay Company's Territory) and of the North-West Territory (including the Pacific Slope), (Toronto: University of Toronto Press, 1973), 809 
police force watching over it. In fact, the various accounts of the hunting expeditions that the majority of Métis participated in demonstrate the fallacy of this assertion. ${ }^{39} \mathrm{~A}$ letter written in 1845 by the future Bishop Alexandre Taché to his mother shortly after arriving in Red River further supports the claim that the Métis were neither unruly nor unable to take charge when disturbances broke out in the settlement. The event Taché describes took place as a dozen Sioux were leaving the settlement after having signed a peace treaty with the Métis. As the Sioux were making their way out, a Saulteaux seeking to avenge the death of his father started shooting at them, only to be stopped by a group of Métis who acted as one to disarm and arrest him. Twenty Métis then proceeded to safely escort the Sioux out of the settlement. 40

This extract is striking because it depicts the Métis as responsible, voluntary, and organized, showing that they could deal with moments of distress on the spot. Their complex hunting party organization required them to be able to handle disorderly conduct. ${ }^{41}$ This letter also suggests that the Métis constituted an almost independent police force or, at the very least, that they could very easily act as such when the situation demanded it. Without the troops that the Council pleaded to keep, the Métis

\footnotetext{
${ }^{39}$ Barkwell, Laurence J. "Early Law and Social Control among the Métis," in Samuel W. Corrigan and Laurence J. Barkwell (eds) The Struggle For

Recognition: Canadian Justice and the Métis Nation (Winnipeg: Pemmican Publications, 1991),14-17

40 Société Historique de Saint Boniface. Fonds CACRSB, 10 sept 1845correspondance envoyée- série Taché ta 0001-00012

${ }^{41}$ Barkwell, Early Law 7-38
} 
constituted the closest thing to armed forces that the settlement possessed which was precisely what the HBC was afraid of. Council's troops left next year despite the company's opposition.

\section{The Royal Commission and the Sayer Trial}

Following this devastating blow to the Council's authority, a letter from the Colonial Office in London arrived, requesting a full account of the conditions and affairs of the Red River settlement. In particular, the letter inquired into the condition of the "mixed and Indian population living there." It requested an inquiry into "charges of maladministration and harsh conduct towards the natives." The colonial office went on to direct attention to "allegations which have been made of an insufficient and partial administration of justice...and the hardships said to follow from an interference...exercised in preventing half breed inhabitants from dealing in furs with each other, on the ground that the privileges of the native Indians of the country do not extend to them." 42

This was the result of a bilingual petition sent by the Métis, primarily composed by Father Belcourt, a Catholic priest, without the consent of his bishop. The petition had quite an impact, leading to the creation of a Royal Commission to investigate the situation and suddenly placing the HBC firmly under the scrutiny of the British

\footnotetext{
42 Minutes of Council, September 20,1848, in E. H. Oliver, The Canadian North-
} West, 345-346. 
government. ${ }^{43}$ One of the main points of the petition was that the HBC's monopoly was highly questionable because it had been established in the Royal Charter of 1670 and had not been renewed or enforced since. The fact that the Métis sent their set of grievances directly to London shows an evident lack of trust in the Council, its laws and justice system.

Their distrust stemmed from the murky attitude of the Council and the Governor. In 1845, a group of Métis sent a compelling petition to Governor Alexander Christie. This petition, however, is not contained in the Minutes of Council but is found in Christie's letters. It may be the case that Christie did not wish to bring the petition to the attention of the Council. It can also be inferred that even if the Council would have received this petition; it would not have taken any action upon it. It is worthwhile paraphrasing the petition in order to show the discriminatory laws which the Métis were subjected to. The petition noted that the Métis were natives of the country which the HBC claimed as its territories. As such, they had the right to hunt and trade in those furs "to the highest bidder." It is noteworthy that the petition was not confrontational. It respected the "rights" of the Company and the laws of England. Their petition raised 14 questions, all having more or less to do with one point: did natives of

43 Isbister Alexander, Kennedy. A few words on the Hudson's Bay Company: With a statement of the grievances of the native and half-caste Indians, addressed to the British Government through their delegates now in London. London: C. Gilpin, 1846. Aborigines Protection Society. The Red River Settlement and the Hudson's Bay Company (London Aborigines' Protection Society, 1848). 
the country have the same rights as Indians? Their questions implied that as "halfbreeds" they were interconnected with their Indian relatives, and that the distinctions made by the company between Indians and halfbreeds were an unfamiliar concept to them. Their petition started as follows:

\section{Red River Settlement, August 29th 1845:}

Sir, Having at this moment a very strong belief that we, as natives of this country, and as halfbreeds, have the right to hunt furs in the Hudson's Bay Company's territories whenever we think proper [...]; likewise having a doubt that natives of this country can be prevented from trading and trafficking with one another; we would wish to have your opinion on the subject, $[\ldots]^{44}$

The Laws of Assiniboia never made any mention of hunting or trade, but they stated, in keeping with the Charter of 1670 , that natives were beyond their jurisdiction (until Adam Thom later decided he was above that law). ${ }^{45}$

44 Signed by: "James Sinclair, Alexis Gaulat, Baptist La Roque, Louis Letende De Batoche,Thomas Logan, William McMillan, John Dease,Antoine Morran, Bat. Wilkie, John Anderson, John Vincent, Thomas McDermot, William Bird, Adali, Trottier, Peter Garioch, Charles Hole, Henry Cook, Joseph Monkman, Spence, Baptist Farman William Henry Gray, A History of Oregon, 1792-1849, Drawn from Personal Observation and Authentic Information. Portland, Oregon: Harris \& Holman, 1870. chapter III

45 In the case of Public Interest vs Capenesseweet, 4 Aug. 1845. Provincial Archives of Manitoba. General Quarterly Court Records of Assiniboia, Book One. 
The very people who were excluded from the Council of Assiniboia and its laws displayed an uncanny knowledge of the system and interest in legal procedures and the charter of 1670. This letter could be considered to be a first step towards Métis instrumentalization of ethnicity and identity as they sought to make the most of the laws through either their heritage or parentage. The Métis' mixed heritage allowed them to associate with both Europeans and Natives, therefore they could claim affiliation with either one group according to the situation. ${ }^{46}$ Christie, in his answer to the petition, asserts the monopoly of the HBC in the whole territory and concluded that "If however any individual among you, or among your fellow citizens, should at any time feel himself embarrassed in any honest purpose by legal doubts, I shall have much pleasure in affording him a personal interview." 47 This last somewhat questionable remark underscores that Métis rights would definitely not be a part of the Laws of Assiniboia, nor of any written agreement - that is, until Recorder Adam Thom decided to try a case of illegal trafficking for the first time ever, during the landmark 'Sayer Trial' of 1849.

Guillaume Sayer was to be tried in May 1849 for illegally trading furs. On the day of the trial, "a great number of armed halfbreeds" 48 waited outside the courthouse. Even after a considerable amount of time,

46 The concept of instrumental ethnicity is developed in Gerhard Ens' essay "Métis Ethnicity, Personal Identity and the Development of Capitalism in the Western Interior. The Case of Johnny Grant."

${ }^{47}$ Begg, Alexander. History of the North-West. Vol.I (www.ourroots.ca) September 5, 1845, 263-264.

48 Provincial Archives of Manitoba. District of Assiniboia Court Records. May 17, $1849,151$. 
Sayer himself did not arrive. Instead, a group of men came and presented themselves as "Delegates of the People." They handed a "paper" to the court. Adam Thom in return told them they could not be received in that capacity and that, according to the Royal Charter, the HBC had exclusive rights of trade. Sinclair, who was among the delegates replied that "many eminent characters in the houses of Parliament in England entertained great doubts as to the validity of the HBC Charter and in support of which assertion he handed to the bench a copy of the Times News for August." 49

At last, Sinclair went to fetch Sayer. He objected to five of the jurors and eleven others were called. The witnesses were interrogated; the jury deliberated and found Sayer guilty. However, mercy was recommended "as it appeared that he thought that he had a right to trade as he and others were under the impression that there was a free trade."50 This event is considered a milestone because it marked the start or proclamation of Métis free trade. ${ }^{51}$ The accounts of the trial, usually concluded by symbolic cheering for free trade miss the significant point that the Sayer Trial was the first and last case of illegal trade in furs tried by the court of Assiniboia. The Governor and Committee had had nothing to do with the initiation of the

49 Ibid.

50Ibid.

51 Giraud, 921 ; Morton, Arthur S. A History of the Canadian West to 1870-71. Being a history of Rupert's Land (The Hudson's Bay Company's Territory) and of the North-West Territory (including the Pacific Slope) Toronto: University of Toronto Press, 1973. 815-6 ; Friesen, Gerald. The Canadian Prairies A History. (Toronto: University of Toronto Press, 2004), 101 
Sayer case $\mathrm{5}^{5}$ - Adam Thom and Governor Christie were its main instigators. ${ }^{53}$ Company officials were well aware of the "illegal" trade but obviously preferred to deal with it discreetly. ${ }^{54}$ The independent trade had previously been kept out of the judicial sphere of Assiniboia. That this was unprecedented demonstrates that the HBC treated the Métis differently from the other citizens of the state of Assiniboia.

It is interesting to note that there are only a couple of passages in the Minutes of Council that mention and condemn illegal trade. ${ }^{55}$ But it is even more compelling to see that in 1848 the Minutes of council retracted the earlier statement and rid the Council of the responsibility of dealing with trade. 56 The status of Assiniboia's inhabitants was delicate because it placed them outside of the commercial sphere of the rest of Rupert's Land. When Recorder Thom decided to try Guillaume Sayer, not only did he exceed his powers, he involuntarily allowed a whole population to use the court of Assiniboia to express its

\footnotetext{
52 Morton, 816.

${ }^{53}$ Chief Factor John Ballenden is supposed to have been part of the instigation, according to Marcel Giraud or Sylvia Von Kirk, but they provide no direct evidence of his responsibility. Thom's ambition to thwart the Métis trade had been expressed rather clearly in a letter to Governor Alexander Christie : " but the experience of the most recent years, during which the traffic between Red River settlement and the Mississippi has been wonderfully extended must have still more decidedly convinced every thinking man, that our half breeds neither valuing time, nor dreading hardship, would, if permitted, overrun the whole country, even to Hudson's Bay and the Frozen Ocean with American goods. » 13-14 of Adam Thom A few Remarks on a pamphlet entitled "A few words on the Hudson's Bay Company, » in a letter to Alexander Christir, Esq., (Governor ofAssiniboia. London : printed by E. Couchman, 1848).

54 See p. 15-16

55 Minutes of Council, E. H. Oliver, The Canadian North West, 311.

56 Ibid., 347.
} 
discontent and to claim the right to trade. The state of Assiniboia and its zealous judge were thus fundamental to the creation of a new era and the dismantling of the old Council.

\section{The People's Council}

Council Minutes following the trial placed the blame for what had happened on Thom, who lost his job as recorder of Rupert's Land but remained a member of the Council. The Council decided to replace Thom with a bilingual judge to rescind the laws concerning imports from the U.S. and to infuse "a certain proportion of Canadian and half breed members" into the Council.57 The Council also affirmed the free trade in furs. Council Minutes include a note concerning Adam Thom and "his willingness in future, to address the court in both languages in all cases involving either Canadian or halfbreed interests." 58 This statement is worthy of our attention not only for its striking quality. It finally acknowledges francophones who had thus far been ignored by the council.

Since then, the Council's resolutions proved much more constructive and increasingly aimed at encouraging the welfare of the colony. Financial grants were given to Catholic and Protestant clergy for the improvement of the settlement's roads, and a printing press was ordered. ${ }^{59}$ The

57 Because the population counted very much on imports from the United States.

58 Minutes of Council. Oliver, North-West, 352.

59 Ibid, 364-365.

Past Imperfect

15 [2009) | () | ISSN 1711-053X | elSSN 1718-4487 
diocese of Rupert's Land was created in 1850 and the institution of postal service via St. Peter. Both were aimed at "bringing the settlement of Red River into nearer connection with her majesty's government." 60 The same year marked the arrival of an important Councilor: Louis Laflèche, a French Canadian Catholic priest. This led to closer ties with the imperial state in subsequent years.

\section{Redefining the role of the laws and the Council of}

\section{Assiniboia}

Laflèche proved instrumental in framing the 1851 revision to the Laws of Assiniboia as he translated and simplified the text. The introduction acknowledges the changes and why they were made:

We have reduced the whole of the existing regulations within the narrow compass of little more than forty resolutions. This brevity we have attained partly by throwing aside all preambles whatever, and partly by omitting all such regulations as would appear never to have been called into practical operation. In pursuit of the same desirable object, we have attempted to simplify and abridge the phraseology...In some instances, too, we have, under correction of

${ }^{60}$ In reaction to threats of the Métis to get « closer » to the United States in the 1847 petition. 
course, regarded the law, not as it is, but as it ought to be. ${ }^{61}$

The introduction is striking for its straightforward character. It discusses at length the links binding the laws of Red River to those of England. It describes in lucid fashion the limits and inadequacy of such laws in the context of the settlement. The text created a space for Assiniboia to legislate independently of English law. ${ }^{62}$ It also introduced the law that natives were outside of the jurisdiction of the Council and were not on the same footing as British subjects. It also dealt with the protection of the settlement, stating that the police, appointed from the population or Red River was "partly soldiers and partly citizens," meaning that they would be accessed on the same laws as everyone else." 63 The new laws were drafted with adequate clarity something which was lacking in the previous version.

Overall, the recast laws of Assiniboia were much more practical and pragmatic. They were stripped of tedious jargon and infused with constructive laws like the introduction of a section about the library and marriage licenses which the Council had the power to issue. The final

\footnotetext{
61 Minutes of Council, E. H. Oliver, The Canadian North West, 369

62 Now the laws of England of that date, independently of their inherent inferiority, are difficult, nay, generally speaking, impossible, to be ascertained, more particularly in such a wilderness as this. We have, therefore, suggested the substitution of the laws of England, as existing at such a date as would render nearly every legal publication in the settlement a work of authority." Report of the law amendment committee, Red River Settlement, May 1851. Oliver, North-West, 369-70.

63 Ibid, 371.
} 
piece of legislation contradicts the Royal Charter of 1670 under which only clergyman could celebrate marriage. Finally, the new laws were published in both French and English, one page facing the other, giving the text a strangely contemporary looking Canadian lay-out.

\section{A Democratic Council: Reshaping Red River}

The Council thus entered a new era. The population of Assiniboia, through constant use of petitions, took an active role in the process of law-making. During the fifteen years before the Sayer Trial, Council Minutes mention three petitions but in the next twenty years, the Council dealt with a staggering ninety one petitions and letters. In this period Council resolutions were much more constructive than in the past. They were increasingly aimed at promoting the welfare of the colony. The petitions drew their effectiveness from the Council's realization that it could not simply impose its rule on the people of Assiniboia without consequences. Both the Sayer Trial and the petitions sent to the Colonial Office that led to the Royal Commission had been major sources of embarrassment for the HBC, partly because they highlighted doubts concerning the validity of the Royal charter of 1670.64 The threat that petitions might be sent to her majesty's government instead of solely to authorities in Assiniboia most definitely

64 Isbister Alexander, Kennedy, A Few Words on the Hudson's Bay Company: With a Statement of the Grievances of the Native and Half-caste Indians, Addressed to the British Government through their Delegates now in London (London: C. Gilpin, 1846). 
led the Council, thereby the HBC, to be more attentive and responsive to the demands and propositions of the colony's inhabitants.

Overall, the population communicated with the Council in order to make requests or complaints or to criticize the Council's decisions. ${ }^{65}$ Many of the meetings dealt with the improvement of roads, the building of bridges, and the general transformation of the colony's landscape. Roads and bridges proved to be such a concern in the 1850s that they were given priority status through the Council's creation of a Board of Works for each district. ${ }^{66}$ Council Minutes portray in detail the colony's evolution into a more "European" agrarian community. Among the obvious benefits stemming from the cooperation between the Council and people were grants for education, relief to flood victims, road repairs, bilingual laws and judicial services. Council Minutes reveal that those who benefited from the Council were local residents who became increasingly estranged from Red River's legislative system.

Some of the petitions sent by individuals or groups complained of the troubles brought by alcohol and the disruption of peace caused by public houses. The settlers showed a certain sense of initiative by sending several propositions on the regulation, sale and distillation of liquor to Councilors. Customs also proved to be a subject of constant deliberations. However, some of the petitions are not easily classified. For instance, in March 1862, the

65 Ibid., 388-389.

66Ibid., 447. 
Council received a petition signed by 465 individuals, making it the most massive written mobilization of Red River's population during the period. This petition did not concern alcohol, bridges or roads but dealt with Paulet Chartrand, a prisoner. The petitioners asked for the early release of Chartrand on account that he "may lose the use of his senses." He was at the head of a large family who depended on him and had been reduced to poverty in his absence. ${ }^{67}$ The petition helped reduce his sentence for manslaughter from ten to six months' imprisonment. ${ }^{68}$ This petition, the support it embodied, and the display of public sentiment for the fate of Chartrand and his family manifest a spontaneous sense of care and solidarity from a large segment of Red River's population, while also demonstrating a certain respect for Assiniboia's justice system.

Contrary to the laws drafted in 1841 which dealt mainly with such things as pigs and stallions roaming, the final version of the Laws of Assiniboia drafted and printed in 1862 contained lengthy additions in the Alcohol section and three pages on custom duties. ${ }^{69}$ New sections were also created regulating "Debtors, Interstate Estates, Marriage Licenses, Contracts for service, Surveyors, and Postal Services." The final Laws of Assiniboia are a testimony to the people's participation in the political process through petitions and reflect the important growth of Red River, a community that began as a young and

67 Ibid., 482-483.

68 Provincial Archives of Manitoba. District of Assiniboia, Courts Records.

69 The other versions of the Law of Assiniboia were manuscripts. 
rudimentary settlement and transformed itself into a selfaware colony developing its infrastructures on a European model.

The new Council seemed to continue to ignore the free trader community that was further estranged from the legislative system of Red River. An 1853 report referred to the free traders but did so only to better alienate them. The report asserted that debtors leaving "the settlement for a period of one year or upwards for a part of this country over which the civil jurisdiction of the courts of the settlement does [not] extend shall be held to be leaving the country." The report excludes those who are employed by the HBC and goes on to state that their property in the settlement shall be seized. ${ }^{70}$ That report was approved by the Councilors and turned into law. ${ }^{71}$ Thus, the Council of Assiniboia pursued a policy of gradual dispossession of the semi-nomadic population.

\section{Conclusion}

Initially, the Council and laws of Assiniboia were anything but promising. From exerting no power whatsoever in the 1820s, by the end of the period it had grown into a small state with power over such things as intestate estates. The mere development of the colony

\footnotetext{
70 That in the case of a debtor who has left the country as above defined, having property in the settlement, such property, or as much of the same as may be deemed equal to the amount of the claim, shall, at the discretion of any two justices be liable ...the competent court may proceed to execute justice in the matter.

71 Ibid., 496.
} 
certainly called for additional laws, but the cooperation between the Council and residents led to the settlement's accelerated growth. Before 1849, the Council deliberately ignored the semi-nomadic population who engaged in hunting. That the nomadic Métis or halfbreeds' activities were estranged from the laws, even though they were part of the settlement and asked for the Council's tutelage, 168 suggests their ostracism was conscious. They were competing with the Hudson's Bay Company while their native kinship protected them from the Royal Charter of 1670; they were "special" citizens of Assiniboia, a notion the state or the company weren't ready to accept. The Council of Assiniboia was the first state to legally marginalize the Métis hunters and traders of Red River. Red River society as a whole actively participated in the dismantling of the Council in its original form. Initially used as an agent of repression by the HBC, the Council was slowly transformed into a hybrid institution as the inhabitants came to use and exert control over it. Following the Sayer Trial, the state of Assiniboia was used to develop the infrastructures of Red River thanks to the Board of Works, which in return facilitated the agriculturists' lifestyle. By promoting the firm establishment of a land based society, the Council of Assiniboia instigated a progressive "eviction" of the free trader population. This successful enterprise would not have been conceivable without the transformation of the Council from a simple rule-setter to something of a democratic mediator. Ironically, the Sayer Trial was largely responsible for the democratization of the Council which in the long run only 
benefitted the sedentary population. The Council later made the territorial laws of Assiniboia concerning the freetraders more rigid. The movements of the Métis traders and hunters became the target of the laws of Assiniboia which subjected them to the dispossession of their property in case of too long an absence while in debt. In the end, the changes made possible thanks to that Métis class contributed to making the settlement less of a home for them, something underscored by the fact that they had already begun to migrate west in the early 1860s. The Council of Assiniboia was in part responsible for the emigration and dispossession of a number of traders and hunters of mixed descent who left for the West or the United States. The state of Assiniboia can be accounted for starting the legal marginalization of the Métis in the 1830s, which marked the beginning of a long series of legal battles about ethnic identity and land rights. 


\section{Bibliography}

Archival Collections

National Archives of Canada

Council of the District of Assiniboia fonds; Hudson's Bay

Company. Private Manuscripts, Assiniboia Council, Records

Provincial Archives of Manitoba

Council of Assiniboia fonds

Archives de l'Archevêché de Saint-Boniface (Centre du

Patrimoine) Fonds Taché; G.A. Belcourt correspondance

Published documents

Aborigines Protection Society. The Red River Settlement and the Hudson's Bay Company, London: Aborigines' Protection Society, 1848.

Draper, William Henry, Hudson's Bay Company: Copy of the letter addressed...to Her Majesty's Secretary of State for the Colonies bearing date the 6th day of May, 1857: Together with a copy of the memorandum therein referred to, relative to the Hudson's Bay Company (Mr Labouchere): Ordered, by the House of Commons, to be printed, 16 June 1857 . London: Government Printer, 1857.

Great Britain. Colonial Office. Hudson's Bay Company: Papers presented by command of Her Majesty to the House of Commons, in pursuance of an address praying that Her Majesty would be graciously pleased to direct that such means as to Her Majesty shall seem most fitting and effectual be taken to ascertain the legality of the powers in respect to 
territory, trade, taxation, and government, which are, or recently have been claimed or exercised by the Hudson's Bay Company, on the continent of North America; under the charter of His Majesty, King Charles the Second issued in the year 1670, or in virtue of any other right or title, except those conveyed by or under the Act 43 Geo. 3, c.138 (extending the criminal jurisdiction of Canadian courts) and $1 \& 2$ Geo. 4, c.66; intituled "An act for regulating the fur trade, and establishing a criminal and civil jurisdiction within certain parts of North America". London: Ordered, by the House of Commons, to be Printed, 1850.

Isbister Alexander, Kennedy. A few words on the Hudson's Bay Company: With a statement of the grievances of the native and half-caste Indians, addressed to the British Government through their delegates now in London. London: C. Gilpin, 1846.

Isbister, Alexander Kennedy. Return to an address of the House of Commons dated 9 February 1849 for copies of any memorials presented to the Colonial Office by inhabitants of the Red River Settlement, complaining of the government of the Hudson's Bay Company: Of the instructions given to the Governor-General of Canada for the investigation of those complaints: Of the reports of the officers appointed by Lord Elgin, or by the Colonial Office for the purposes of such investigation: And of any correspondence which has passed between the Colonial Office and the Hudson's Bay Company and the inhabitants of the Red River Settlement respectively 
upon the subject of the above memorial. London: Queen's Printer, 1849.

Oliver. E. H. The Canadian Northwest Its Early Development and Legislative Records Minutes of the Council of the Red River Colony and the Northern Department of Rupert's Land. Vol I-II. Ottawa: Government Printing Bureau, 1914.

Thom, Adam. A few remarks on a pamphlet entitled "A few words on the Hudson's Bay Company," in a letter to Alexander Christie, Esq., Governor of Assiniboia. London: Printed by E. Couchman, 1848.

Secondary Sources

Baker, Robert H. "Creating Order in the Wilderness: Transplanting the English Law to Rupert's Land, 1835-51," Law and History Review, Vol. 17, No. 2 (Summer 1999).

Barkwell, Laurence J. "Early Law and Social Control among the Métis." In The Struggle For Recognition: Canadian Justice and the Métis Nation. Ed. Samuel W. Corrigan and Laurence J. Barkwell. Winnipeg: Pemmican Publications, 1991.

Begg, Alexander. History of the North-West. 3 vols. Toronto: Hunter, Rose, 1894-1895.

Bindon, Kathryn. "Hudson's Bay Company Law: Adam Thom and the Institution of Order in Rupert's Land 1839- 
54," in Essays in the History of Canadian Law, ed. David Flaherty (Toronto: The Osgoode Society, 1981).

Brogden, Mike. "Law and Criminal Labels: The Case of the French Métis in Western Canada, The Journal of Human Justice, Vol.1, No. 2, Spring 1990.

Bumsted, J. M. Trials and Tribulations: The Red River Settlement and the Emergence of Manitoba 1811-1870. Winnipeg : Great Plains Publications, 2003.

Cellar, André. Punir, enfermer et réformer au Canada, de la Nouvelle France à nos jours. Brochure de la Société Historique du Canada n ${ }^{\circ} 60$. Ottawa, 2000.

Dick, L. "The Seven Oaks Incident and the Construction of a Historical tradition, 1816 to 1970," Journal of the Canadian Historical Association, 1991.

Dorge, Lionel. "The Metis and Canadien Councillors of Assiniboia: Part III" Beaver [Canada] 1974 305(3).

Gerhard, Ens. "Métis Ethnicity, Personal Identity and the Development of Capitalism in the Western Interior: The Case of Johnny Grant," in Binnema, Theodore (et al) (eds)., From Rupert's Land to Canada. Alberta: University of Alberta Press, 2001. 
Foster, John E. "Wintering, the Outsider Adult Male and the Ethnogenesis of the Western Plains Métis" From Rupert's Land to Canada. Alberta: University of Alberta Press, 2001.

Foster, Hamar. "Long-Distance Justice: The Criminal Jurisdiction of Canadian Courts West of the Canadas, 17631859," The American Journal of Legal History, Vol. 34, No. $1 . \quad$ |74 (Jan., 1990).

Giraud, Marcel. Le Métis Canadien: Son rôle dans l'histoire des provinces de l'Ouest (en deux tomes). Paris: Institut d'éthnologie, Musée de l'homme, Paris, 1945.

Goldring, Philip. "Labour Records of the Hudson's Bay Company 1821-1870." Archivaria, № 11 (Winter 1980, 181)

Healy, W.J. Women of Red River. Winnipeg: Russell, Lang \& Co. Ltd, 1923.

Howard, Joseph Kinsey. L'Empire des Bois-Brûlés, traduit par Ghislain Pouhot. Edition des Plaines, Saint Boniface, 1989.

Jefferson, Christie. Conquest by Law. Solliciteur General Collection, Aboriginal People's collection, 1994.

Martel, Gilles. Le Messianisme de Louis Riel, Waterloo, Ont. : Wilfrid Laurier University Press, 1984. 
Marwick, Ernest W. “Chief Factor James Sutherland and his Orkney Correspondence. Beaver [Canada] 1966, 297 (Winter)

Morton, Arthur S. A History of the Canadian West to 187071. Toronto: University of Toronto Press, 1939.

Pannekoek, Frits. A Snug Little Flock: The Social Origins of the Riel Resistance, 1869-70. Winnipeg: Watson \& Dwyer Publishing, 1991.

Ross, Alexander. The Red River Settlement: its Rise, Progress, and Present State / with some account of the native races and its general history to the present day. Edmunton: Hurtig, 1972.

Siamandas, George. "The Council of Assiniboia Pioneering a kind of Democracy at Red River." Site Winnipeg Time Machine.http://www.siamandas.com/time_machine/PAGE S/early_manitoba/COUNCIL_OF_ASSNIBIA.htm

Stanley, George F.G. - The Birth of Western Canada: A History of the Riel Rebellions. Toronto: University of Toronto Press, 1960.

Van Kirk, Sylvia. Many Tender Ties: Women in Fur Trade Society, 1670-1870. Winnipeg: Watson \& Dwyer Publications, 1999. 